\title{
Interaction patterns on body size and health on Instagram and associated factors in nutrition students: an exploratory study
}

\section{Padrões de interação sobre tamanho \\ corporal e saúde no Instagram e fatores associados em estudantes de nutrição: um estudo exploratório}

\author{
Pabyle Alves FLAUZINO1 ${ }^{1}$ iD) 0000-0003-0872-5690 \\ Antonio Augusto Ferreira CARIOCA ${ }^{2}$ ID 0000-0002-1194-562X
}

A B S T R A C T

\section{Objective}

To identify interaction patterns on body size and health on Instagram and associated factors in nutrition students.

\section{Methods}

A total of 406 students (78\% female) were included in this cross-sectional study. Instagram sociodemographic, academic and interaction data (Instagram time of use, exposure frequency to contents on body size and health, Instagram as a source of information and number of followers) were collected using a self-administered virtual questionnaire. A factor analysis by main component was used to derive the interaction patterns of Instagram as well as regression analyses to test the association of the patterns with the sociodemographic and academic factors.

\footnotetext{
${ }^{1}$ Universidade Estadual do Ceará, Centro de Ciências da Saúde, Programa de Pós-Graduação em Nutrição e Saúde. Fortaleza, CE, Brasil.

2 Universidade de Fortaleza, Departamento de Nutrição, Programa de Pós-Graduação em Saúde Coletiva. Av. Washington Soares, n. 1321, Edson Queiroz, 60811-905, Fortaleza, CE, Brasil. Correspondence to: A.A.F. CARIOCA. E-mail: <carioca@unifor.br>.

Support: Conselho Nacional de Desenvolvimento Científico e Tecnológico (CNPq, Brazilian National Council for Scientific and Technological Development) (Procces 422721/2018-2).

Article elaborated from dissertation by P. A. FLAUZINO, entitled "Influência sociocultural das mídias, imagem corporal e preconceito relacionado ao peso em estudantes de nutrição". Universidade Estadual do Ceará; 2021.
}

How to cite this article

Flauzino PA, Carioca AAF. Interaction patterns on body size and health on Instagram and associated factors in nutrition students: an exploratory study. Rev Nutr. 2021;34:e200314. https://doi.org/10.1590/1678-9865202134e200314 


\section{Results}

Three interaction patterns were observed on body size and health, named: "Fitness Pattern"; "Body Positivity Pattern" and "High Engagement Pattern". Private Institutions' Students who are on or have been on a diet and studying in the first semesters were associated with the "Fitness Pattern" $(p<0.05)$. Female students, from public institutions, who changed their weight during the course and whose family's head had higher education, were associated with the "Body Positivity Pattern" $(p<0.05)$. Female students, younger and on a diet, were associated with the "High engagement Pattern" $(p<0.05)$

\section{Conclusion}

Gender, type of educational institution and diet practice of nutrition students are the factors that are most associated with different patterns of interaction on body size and health on Instagram.

Keywords: Body Image. Mental Health. Social Networking.

\section{R E S U M O}

\section{Objetivo}

Identificar padrões de interação sobre tamanho corporal e saúde no Instagram e os fatores associados em estudantes de nutrição.

\section{Métodos}

Um total de 406 estudantes (78\% do sexo feminino) foram incluídos neste estudo transversal. Dados sociodemográficos, acadêmicos e de interação no Instagram (tempo de uso, frequência da exposição a conteúdos sobre tamanho corporal e saúde, o Instagram como fonte de informação e número de seguidores) foram coletados por questionário virtual autoaplicável. Uma análise fatorial por componente principal foi empregada para derivar os padrões de interação da rede social em questão, e análises de regressão testaram a associação dos padrões com os fatores sociodemográficos e acadêmicos.

\section{Resultados}

Foram observados três padrões de interação sobre tamanho corporal e saúde, nomeados de: "Padrão Fitness"; "Padrão Positividade Corporal"; e "Padrão Alto Engajamento". Estudantes dos primeiros semestres, de instituições privadas e que fazem ou já fizeram dietas foram associados ao "Padrão Fitness" $(p<0,05)$. Estudantes do sexo feminino, de instituição pública, que modificaram o peso durante o curso e que tem chefe familiar com alta escolaridade tiveram associação com o "Padrão Positividade Corporal" $(p<0,05)$. Estudantes do sexo feminino, mais jovens e que fazem dieta se associaram ao "Padrão alto engajamento" ( $p<0,05)$.

\section{Conclusão}

Em relação a estudantes de nutrição, sexo, tipo de instituição de ensino e prática de dietas são os fatores que mais se associam aos diferentes padrões de interação sobre tamanho corporal e saúde no Instagram.

Palavras-chave: Imagem Corporal. Saúde Mental. Rede Social.

\section{INTRODUCTION}

Instagram is the world's leading image-sharing social network [1]. In relation to images about body size and health, the ideal Fitness predominates [2]. The focus of ideal Fitness is lean-athletic appearance for women and muscular display for men, coupled with restrictive diets, work out and "before and after" body images [3]. People who are more exposed to Fitness content have higher levels of body vigilance, body dissatisfaction, self-objectification and eating disorders [4-6]. On the other hand, rejecting the hegemonic model of the Fitness content, the Body Positivity movement has been getting popular in Instagram [7]. The objective of this content is to promote criticism of the dominant slim ideal and to value bodies of all sizes, shapes and appearances [8]. Experimental studies have demonstrated that viewing Body Positivity images reduces body dissatisfaction, negative mood and increases body appreciation and self-compassion $[8,9]$. 
Thus, body positivity content can be a consumption option in order to preserve mental health, especially in populations at high risk of body dissatisfaction and eating disorders [5].

Nutrition students are more susceptible to body dissatisfaction when compared to university students from other courses [10]. One in three nutrition students is motivated to join the course because of issues related to body image and eating disorders [11]. Nutrition courses involve intimate exposure to the body topic, and can develop or worsen mental health problems in this population and negatively influence professional practice [12]. This scenario can be modulated depending on the interaction of students with Instagram, such as: viewing different content related to body size and health (i.e., Fitness and Body Positivity); Instagram time of use; number of followers; and as a source of information [13]. However, little is known about the interaction patterns associated with body size and health in Instagram by these students. Knowing these patterns makes it easier to understand how students relate to the different Instagram interaction variables.

Furthermore, it seems important to investigate whether sociodemographic or academic factors (e.g., semester, public or private institution) are associated with interaction patterns in nutrition students on body size and health on Instagram. With this, it is possible to identify groups of students who are more exposed to unhealthy or protective content for mental health, in addition to directing interaction on Instagram in a safe way. Thus, the aim of the present study was to identify interaction patterns on body size and health on Instagram and associated factors in nutrition students.

\section{METHODS}

The present study is a cross-sectional analysis of the Brazilian Nutritionist Health Study - NutriHS cohort, that has a previously published protocol [14]. The investigation was approved by the Research Ethics Committee of the Universidade Estadual do Ceará (CAAE: 95402618.3.0000.5534). All those who participated in the survey signed the Free and Informed Consent Form.

For the sample calculation, an unknown prevalence of $50 \%$ with a confidence interval of $95 \%$ was considered, totaling 384 individuals. Data collection was carried out between June 2019 and June 2020, in 11 of the 28 nutrition courses available in the State of Ceará. Nutrition students of both genders, aged between 18 and 40 years, regularly enrolled in Higher Education Institutions (HEls) were recruited. Students who did not have Instagram, pregnant women, lactating women and those with incomplete data were excluded. Interaction data on Instagram body size and health, sociodemographic and academic profile were collected using a self-administered questionnaire on the website [14].

Sociodemographic variables included age, gender, self-reported skin color, family income, number of people in the household and head of household's education and work time (hours). To assess the academic characteristics, the semester and nature of the HEls were recorded. Body mass and height were self-reported to calculate the Body Mass Index (BMI). Any diet and voluntary modification of body weight after entering the course were also recorded.

Data to assess the interaction on Instagram, time of use, number of followers, frequency of exposure to content related to Fitness and Body Positivity and the use of Instagram as a source of information were collected. Regarding Instagram time of use, students reported the average daily time recorded during the previous week by the Instagram app itself (Instagram app > menu "your activity" > "daily average for the last week"). The number of followers the students had was also directly recorded (Instagram app > number of followers). To assess the respondents' exposure to content related to Fitness and Body Positivity on Instagram, a five-item structured questionnaire was developed, answered on a Likert-type scale ranging from 1 ("Never") to 5 ("Always"). The items associated with Fitspiration were: (1) "I receive content associated with Fitness (i.e., low-calorie diets, slim and/or toned bodies; exercises for hypertrophy and/or 
weight loss", and; (2) "I receive content claiming that slim body is the only synonym of health". The items associated with Body Positivity content were: (1) "I receive content associated with body diversity (i.e., bodies of different sizes, health for all sizes, neutrality on body weight or body positive movement)", and; (2) "I receive content stating that body weight is not always a predictor of health". The last question was: "How often is Instagram content a source of information about what a healthy body is".

Data normality was assessed using the Kolmogorov-Smirnov test. Quantitative variables were presented as mean \pm SD and median $\left(25^{\text {th }}-75^{\text {th }}\right.$ percentile) for data with normal and non-normal distribution, respectively. Qualitative variables were presented by absolute and relative frequencies (\%). Comparisons between genders were made using the t test of independent samples, Mann-Whitney $U$ test and chi-square. Factor analysis by principal component was employed to derive the interaction patterns in Instagram. Sample adequacy was verified using the Kaiser-Meyer-Olkin (KMO) index and Bartlett's sphericity test, where KMO values $>0.50$ and $p<0.05$, respectively, were considered acceptable. The number of factors (standards) to be retained was determined as follows: initial criteria of eigenvalues $>1.0$ and Scree plot analysis with subsequent interpretation of each factor. The Varimax method was used. The patterns were named according to the time of use of Instagram, number of followers, frequency of exposure to Fitspiration and Body Positivity and use of Instagram as a source of information scored in each factor (factorial load $\geq 0.6$ or $\leq-0.6$ ). Subsequently, standardized factor score coefficients were estimated by the regression approach. For the association between interaction patterns (dependent variable) and sociodemographic and academic data (independent variables) a multiple linear regression model with forward strategy was used, considering $p<0.20$ in the univariate model as an input parameter in the multiple model.

\section{R E S U L T S}

The study included 406 nutrition students, mostly female (78\%), from private HEls (73.3\%), enrolled from the $5^{\text {th }}$ semester $(58.3 \%)$. The description of the sample is found in Table 1.

Table 1 - Description of sociodemographic and academic data of nutrition students. Fortaleza (CE), Brazil, 2021.

\begin{tabular}{|c|c|c|c|c|}
\hline Variables & Total $(n=406)$ & Female $(n=317)$ & Male $(n=89)$ & p-value \\
\hline Age (years) \# & $22(20-27)$ & $23(21-27)$ & $22(20-26)$ & 0.669 \\
\hline BMI $\left(\mathrm{kg} / \mathrm{m}^{2}\right)^{¥}$ & $23.9 \pm 3.9$ & $23.7 \pm 4.0$ & $24.9 \pm 3.3$ & 0.010 \\
\hline People in the household ${ }^{*}$ & $3.6 \pm 1.4$ & $3.5 \pm 1.3$ & $4 \pm 1.5$ & 0.005 \\
\hline Skin color, n (\%)* & & & & 0.784 \\
\hline White & $192(47.3 \%)$ & $149(47.0 \%)$ & $43(48.3 \%)$ & \\
\hline Do not know & $14(3.4 \%)$ & $10(3.2 \%)$ & $4(4.5 \%)$ & \\
\hline Family income, $\mathrm{n}(\%)^{*}$ & & & & 0.966 \\
\hline$<5$ minimum wages & $275(67.7 \%)$ & $214(67.5 \%)$ & $61(68.5 \%)$ & \\
\hline$\geq 5$ minimum wages & $100(24.7 \%)$ & $79(24.9 \%)$ & $21(23.6 \%)$ & \\
\hline Do not know & $31(7.6 \%)$ & $24(7.6 \%)$ & $7(7.9 \%)$ & \\
\hline Work, n (\%)* & $128(31.5 \%)$ & $100(31.5 \%)$ & $28(31.5 \%)$ & 0.988 \\
\hline Private & $340(83.7 \%)$ & $269(84.8 \%)$ & $71(79.8 \%)$ & \\
\hline Public & $66(16.3 \%)$ & $48(15.2 \%)$ & $18(20.2 \%)$ & \\
\hline Semester, n (\%)* & & & & 0.053 \\
\hline$\leq 4^{\text {th }}$ semester & $169(41.7 \%)$ & $124(39.1 \%)$ & $45(50.6 \%)$ & \\
\hline$\geq 5^{\text {th }}$ semester & $237(58.3 \%)$ & $193(60.9 \%)$ & $44(49.4 \%)$ & \\
\hline
\end{tabular}

Note: \#Mann-Whitney U Test for comparison between genders, presented as median $\left(25^{\text {th }}-75^{\text {th }}\right.$ percentile). ${ }^{*}$ Chi-square test for comparison between genders, presented as absolute and relative frequency (\%). ${ }^{¥}$ t test of independent samples for comparison between genders, presented as mean \pm SD. BMI: Body mass index. HEl: Higher Education Institution. 
Table 2 shows the results of interaction with Instagram of nutrition students. Students indicated an average of 2 hours daily use of Instagram and 1,000 followers. Female students had longer Instagram use and more exposure to body positivity content ( $p<0.05$ for all).

From the analysis of factors by main component to derive Instagram content patterns, three interaction patterns were obtained. Pattern 1 was associated with the frequency of exposure to "Fitspiration" and "only the slim body as a synonym of health"; it was thus named "Fitness Pattern". Pattern 2 was associated with the frequency of exposure to the content "Body Positivity", "Body weight is not always a predictor of health" and Instagram as "Source of information on body size and health." Thus, pattern 2 was named "Body Positivity Pattern." The third pattern was associated with Instagram daily length of use and the number of followers, thus named "High Engagement Pattern." The variables that derived the interaction patterns on Instagram are presented in Table 3.

Table 2 - Instagram interaction on body size and health in nutrition students. Fortaleza (CE), 2021.

\begin{tabular}{lcccc}
\hline Variables & Total & Female & Male & $p$-value \\
\hline Usage time (min/day) & $120(60-180)$ & $120(60-180)$ & $80(60-170)$ & 0.037 \\
Number of followers & $1000(539-1502)$ & $1003(559-1504)$ & $956(497-1410)$ & 0.708 \\
Exposure frequency (1 to 5) & & & & \\
Fitness-related content & $3(3-4)$ & $3(3-4)$ & $4(3-4)$ & 0.150 \\
Body Positivity Content & $4(3-4)$ & $3(2-3)$ & $3(2-4)$ & $<0.001$ \\
Only thin body synonym of health & $3(2-3)$ & $4(3-4)$ & $3(2-3,5)$ & 0.390 \\
Body weight is not always a predictor of health & $3(3-4)$ & $3(3-4)$ & $3(2-4)$ & 0.010 \\
Source of information on body size and health & $3(3-4)$ & & 0.109 \\
\hline
\end{tabular}

Note: Data were presented as median $\left(25^{\text {th }}-75^{\text {th }}\right.$ percentile). Comparison between genders was performed using the Mann-Whitney $U$ Test. ${ }^{\mathbf{f}}$ Frequency reported by a Likert-type scale from 1 (Never) to 5 (Always).

Table 3 - Description of interaction patterns found on Instagram in nutrition students. Fortaleza (CE), Brazil, 2021.

\begin{tabular}{lccc}
\hline Variables & Pattern 1 Fitness & Pattern 2 Body Positivity & Pattern 3 High Engagement \\
\hline Usage time (min/day) & -0.061 & 0.117 & 0.810 \\
Number of followers & 0.205 & -0.034 & 0.671 \\
Fitness Content & 0.816 & 0.213 & 0.055 \\
Body Positivity Content & 0.147 & 0.834 & 0.095 \\
Only thin body synonym of health & 0.825 & 0.025 & 0.095 \\
Body weight is not always a predictor of health & -0.025 & 0.857 & 0.006 \\
Source of information on body size and health & 0.146 & 0.662 & 0.014 \\
\% explained variance & 20.5 & 27.6 & 16.1 \\
\hline
\end{tabular}

Note: *Patterns obtained by factor analysis by principal component. Factor loads $\geq 0.6$ or $\leq-0.6$ were considered significant.

Table 4 shows the result of associations between interaction patterns on Instagram and the sociodemographic and academic variables. It was noted that the older the age, the less adherence to the High engagement pattern. Male students had an inverse relationship of exposure to the contents of the Body Positivity and High Engagement standards. Fitspiration was inversely associated with the public institution, more advanced semesters and never experienced a diet. 
Table 4 - Interaction patterns and sociodemographic and academic data of nutrition students. Fortaleza (CE), Brazil, 2021.

\begin{tabular}{|c|c|c|c|c|c|c|}
\hline \multirow{3}{*}{ Variables } & \multicolumn{2}{|c|}{ Pattern 1} & \multicolumn{2}{|c|}{ Pattern 2} & \multicolumn{2}{|c|}{ Pattern 3} \\
\hline & \multicolumn{2}{|c|}{ Fitspiration } & \multicolumn{2}{|c|}{ Body Positivity } & \multicolumn{2}{|c|}{ High Engagement } \\
\hline & Beta $^{*}$ & $95 \% \mathrm{Cl}$ & Beta $^{*}$ & $95 \% \mathrm{Cl}$ & Beta $^{*}$ & $95 \% \mathrm{Cl}$ \\
\hline Age (years) & 0.02 & $-0.10 ; 0.35$ & -0.01 & $-0.02 ; 0.01$ & -0.03 & $-0.05 ;-0.01$ \\
\hline \multicolumn{7}{|l|}{ Gender } \\
\hline Female & 1 & & 1 & & 1 & \\
\hline Male & 0.12 & $-0.10 ; 0.35$ & -0.55 & $-0.77 ;-0.32$ & -0.31 & $-0.54 ;-0.07$ \\
\hline \multicolumn{7}{|l|}{$\mathrm{HEI}$} \\
\hline Private & 1 & & 1 & & & \\
\hline Public & -0.38 & $-0.63 ;-0.12$ & 0.35 & $0.09 ; 0.60$ & & \\
\hline \multicolumn{7}{|l|}{ Semester } \\
\hline $1-4$ & 1 & & & & 1 & \\
\hline$>5$ & -0.25 & $-0.45 ;-0.05$ & & & -0.08 & $-0.28 ; 0.12$ \\
\hline \multicolumn{7}{|l|}{ Family's head education } \\
\hline$\leq 10$ years of study & & & 1 & & & \\
\hline$>10$ years & & & 0.31 & $0.10 ; 0.51$ & & \\
\hline \multicolumn{7}{|l|}{ Skin color } \\
\hline White & 1 & & 1 & & 1 & \\
\hline Black/Brown & -0.08 & $-0.27 ; 0.11$ & -0.18 & $-0.37 ; 0.01$ & 0.16 & $-0.03 ; 0.36$ \\
\hline Other & -0.32 & $-0.84 ; 0.19$ & -0.30 & $-0.81 ; 0.22$ & 0.22 & $-0.32 ; 0.75$ \\
\hline \multicolumn{7}{|c|}{ Have you ever been on a diet } \\
\hline Yes & 1 & & & & & \\
\hline No & -0.23 & $-0.42 ;-0.03$ & & & & \\
\hline \multicolumn{7}{|l|}{ Is dieting } \\
\hline Yes & 1 & & & & 1 & \\
\hline No & -0.50 & $-0.74 ;-0.25$ & & & -0.27 & $-0.52 ;-0.02$ \\
\hline \multicolumn{7}{|c|}{ Modified weight during the course } \\
\hline Yes & & & 1 & & 1 & \\
\hline No & & & -0.38 & $-059 ;-0.17$ & -0.10 & $-0.32 ; 0.12$ \\
\hline
\end{tabular}

Note: "Regression coefficient obtained by linear regression. 95\% Cl: Confidence Interval. HEl: Higher Education Institution.

\section{DISCUSSIO N}

Three interaction patterns on body size and health were observed on Instagram in nutrition students: "Fitspiration Pattern"; "Body Positivity Pattern" and "High Engagement Pattern". The "Fitspiration Pattern" was less consumed by students of Public HEls and by students who were not dieting or had never dieted. The "Body Positivity Pattern" was inversely associated with male students and students who voluntarily changed their body weight after entering the nutrition course. On the other hand, the "High Engagement Pattern" was inversely associated with older, male students who were not dieting. On Instagram it is possible for the user to "follow" and be exposed to different contents related to body and health at the same time [2]. Determining the standards allows the most frequently consumed content to be defined. In this way, the three standards defined by us allow a broader assessment of the content consumed by students and enable targeting of educational actions.

We found that students from private HEls were associated with the "Fitspiration Pattern" on Instagram. It is possible to observe a difference in nature between public and private HEls regarding education [15]. While public HEls have a greater predominance of research, extension and postgraduate studies (stricto sensu), Private HEls provide education that is more focused on the labor market $[16,17]$. This fact can modulate the students' interest and make them more inclined to the consumption of content focused on 
health and aesthetics (Fitness), considering the hegemony of the Fitness market in society [18]. With the fast popularization of social networks, it is essential that the curricular contents start to consider them as a fundamental part of training, especially in the Social, Human and Economic Sciences as recommended by the National Curriculum Guidelines for the undergraduate courses in nutrition $[19,20]$. The inclusion of these contents can mitigate the aggravation or development of eating disorders and favor practices not centered on the control of students' bodies and, consequently of populations, in order to ensure health promotion, pluralism and cultural diversity covering also the body.

Students who are not on a diet or who have never dieted have an inverse association with the "Fitspiration Pattern". This finding corroborates what was found by Elise et al. [21], who demonstrated that users who usually follow Fitness contents are more concerned about what they eat and the risks of eating disorders. It is important to emphasize that the nature of the studies investigating this subject still does not allow definition of the causal relationship and the direction of the association between the exposure to content, mental health problems and graduation in nutrition. In any case, it is undeniable that this group is at greater risk when accessing content that focuses too much on slim-athletic appearance, and educational measures addressing this risk should be employed during student training [22].

In our findings, women and students with a history of weight change after entering the nutrition course showed a greater association with the "Body Positivity Pattern". Body Positivity images appear on Instagram as a counter-hegemonic response to the standardized body model (i.e., thin and toned), especially female [7]. In this way, it becomes an alternative for thousands of users who do not identify themselves or who suffer the aesthetic pressure imposed by the current model [8]. Despite the aesthetic pressure that reaches the male audience, men are not the target of continuous media objectification and hypersexualization [23]. Another important side-feature of the images covering Body Positivity is the narrative related to body weight in a neutral and inclusive way, different from that found in traditional media (e.g.: magazines and TV programs) [24]. One of these images proposal is the Health At Every Size ${ }^{\circledR}$ aspect, in which body weight is not central to health [25]. Thus, it is possible that students who suffer greater aesthetic pressure such as women and those who wish to change their body weight voluntarily, access this content more frequently because they find less hostile possibilities to deal with their body and health. Furthermore, we found that students associated with the "Body Positivity Pattern" use Instagram as a source of information on body size and health more frequently. The body positivity approach is relatively new, therefore, it is possible that there is little information on this topic in the HEls education programs [8]. We hypothesize that having access to this content can optimize the professional life of these students, as they will be able to improve their respect for the plurality of individuals and communities, as recommended by the nutritionists' code of ethics and conduct [26].

We found an interaction pattern that we named "High Engagement", which was related to Instagram longer usage time and greater number of followers. This pattern was inversely associated with older and male students. As in other studies, one can observe a lower prevalence of male and older users of Instagram [27]. This trend follows the app's specific profile, which is still more accessed by women and young people [1]. Despite the association between mental health problems and the use and content of Instagram, the positive potential of this network in the routine of the general population and contemporary professions is undeniable $[28,29]$. By using Instagram, students can optimize knowledge development outside the classroom, and become content producers, increasing and disseminating nutrition knowledge to the general population [13].

Despite the growing interest in the matters addressed in this work, to our knowledge this is one of the first works addressing this subject in this country. Our findings demonstrate the importance of nutrition undergraduate courses to include in their pedagogical projects debates on the potential risks and benefits 
of interacting with social networks, in order to keep up with the complexity and challenges of the digital age for students and future professionals. In addition, our results point to groups of students who are more associated with contents focused on Fitness (e.g., students from private HEls, early semesters and who were on or are on a diet) and, consequently, are at greater risk for mental health problems. These issues become increasingly urgent, as the trend towards the routine use of social networks by students and professionals is irreversible [29].

Despite interesting findings, we have to point out some limitations in our study. First, the questionnaire used to describe students' interaction with Instagram generating the interaction patterns is not validated. The lack of instruments for this purpose has been frequently reported in the literature [27]. However, we performed a pre-test of the questionnaire with 25 students in nutrition education and we were able to confirm the adequacy and consistency of the data. We further emphasize that Instagram usage time as well as the number of followers have been directly measured. Second, our sample consisted of young students from the Northeastern region of Brazil and, therefore, the extrapolation of our results to other populations should be performed with caution.

\section{CONCLUSION}

Nutrition education students display three interaction patterns on Instagram, named "Fitspiration", "Body Positivity" and "High Engagement". Gender, type of HEl and diet practices are the factors that are most associated with the different interaction patterns on Instagram. Knowing these patterns, the associated sociodemographic and academic factors will facilitate an educational guidance on the interaction on Instagram in nutrition students, since this population carries an important risk factor for problems with body image and eating disorders.

\section{CONTRIBUTORS}

PA FLAUZINO contributed to the conception and design of the study, data collection, data analysis and interpretation, article review and approval of the final version. AAF CARIOCA contributed to the conception and design of the study, analysis and interpretation of data, review of the article and approval of the final version.

\section{REFERENCES}

1. RSPH. Instagram Ranked Worst for Young People's Mental Health [Internet]. 2017 [cited 2020 Nov 8]. Available from: https://www.rsph.org.uk/about-us/news/instagram-ranked-worst-for-young-people-s-mental-health.html

2. Di Bisceglie S, Arigo D. Perceptions of \#fitspiration activity on Instagram: patterns of use, response, and preferences among fitstagrammers and followers. J Health Psychol. 2019 [cited 2020 Nov 8]; Available from: https://pubmed. ncbi.nlm.nih.gov/31455118/

3. Boepple L, Ata RN, Rum R, Thompson JK. Strong is the new skinny: a content analysis of fitspiration websites. Body Image [Internet]. 2016 [cited 2020 Nov 8];17:132-5. Available from: https://pubmed.ncbi.nlm.nih.gov/27045871/

4. Dumas A-A, Desroches S. Women's use of social media: what is the evidence about their impact on weight management and body image? Curr Obes Rep. 2019 [cited 2020 Nov 8];8(1):18-32. Available from: https://link. springer.com/article/10.1007/s13679-019-0324-4

5. Robinson L, Prichard I, Nikolaidis A, Drummond C, Drummond M, Tiggemann M. Idealised media images: the effect of fitspiration imagery on body satisfaction and exercise behaviour. Body Image. 2017;22:65-71.

6. Prichard I, McLachlan AC, Lavis T, Tiggemann M. The impact of different forms of \#fitspiration imagery on body image, mood, and self-objectification among young women. Sex Roles. 2018 [cited 2020 Nov 22];78(11-12):789-98. Available from: https://scinapse.io/papers/2754504557 
7. Cohen R, Irwin L, Newton-John T, Slater A. \#bodypositivity: a content analysis of body positive accounts on Instagram. Body Image [Internet. 2019 Jun 1 [cited 2020 Nov 8];29:47-57. Available from: https://pubmed.ncbi. nlm.nih.gov/30831334/

8. Tiggemann M, Anderberg I, Brown Z. \#loveyourbody: the effect of body positive instagram captions on women's body image. Body Image. 2020 [cited 2020 Nov 8];33:129-36. Available from: https://pubmed.ncbi.nlm.nih. gov/32151992/

9. Slater A, Varsani N, Diedrichs PC. \#fitspo or \#loveyourself? the impact of fitspiration and self-compassion Instagram images on women's body image, self-compassion, and mood. Body Image. 2017[cited 2020 Nov 8];22:87-96. Available from: https://pubmed.ncbi.nlm.nih.gov/28689104/

10. Mahn HM, Lordly D. A review of eating disorders and disordered eating amongst nutrition students and dietetic professionals. Can J Diet Pract Res. 2015 [cited 2020 Nov 8];76(1):38-43. Available from: https://pubmed.ncbi.nlm. nih.gov/26067246/

11. Hughes R, Desbrow B. Aspiring dietitians study: A pre-enrolment study of students motivations, awareness and expectations relating to careers in nutrition and dietetics. Nutr Diet. 2005;62(2-3):106-9. https://doi.wiley. com/10.1111/j.1747-0080.2005.00015.x

12. Houston CA, Bassler E, St. Germain A. Ethical considerations when students experience an active eating disorder during their dietetics training. J Acad Nutr Diet. 2015 [cited 2020 Nov 8];115(10):1715-7. Available from: http:// jandonline.org/article/S2212267215012605/fulltext

13. Dunne DM, Lefevre C, Cunniffe B, Tod D, Close GL, Morton JP, et al. Performance nutrition in the digital era: an exploratory study into the use of social media by sports nutritionists. J Sports Sci. 2019 [cited 2020 Nov 8];37(21):2467-74. Available from: https://pubmed.ncbi.nlm.nih.gov/31345110/

14. Folchetti LD, Silva IT, Almeida Pititto B, Ferreira SRG. Development of web-based system for a cohort study: the Brazilian e-NutriHS. In: Healthinf 2015 - 8th International Conference on Health Informatics, Proceedings; Part of 8th International Joint Conference on Biomedical Engineering Systems and Technologies, BIOSTEC 2015 [Internet]. SciTePress; 2015 [cited 2020 Nov 22]. p. 574-9. Available from: https://pubmed.ncbi.nlm.nih.gov/26262178/

15. Durham ER. O ensino superior no Brasil: público e privado. São Paulo; 2003. p. 45.

16. Sguissardi V. Educação superior no Brasil: democratização ou massificação mercantil? Educ Soc. 2015;36.

17. Instituto Nacional de Estudos e Pesquisas Educacionais Anísio Teixeira (Brasil). Resumo Técnico do Censo da Educação Superior 2018. Brasília: Instituto; 2007 [cited 2020 Nov 22]. Available from: http://portal.inep.gov.br/informacao-dapublicacao/-/asset_publisher/6JYIsGMAMkW1/document/id/6960488

18. Recine E, Gomes RCF, Fagundes AA, Pinheiro ARO, Teixeira BA, Sousa JS, et al. A formação em saúde pública nos cursos de graduação de nutrição no Brasil. Rev Nutr. 2012[cited 2020 Nov 22];25(1):21-33. Available from: http:// www.scielo.br/scielo.php?script=sci_arttext\&pid=S1415-52732012000100003\&lng=en\&nrm=iso\&tlng=pt

19. Elhai JD, Dvorak RD, Levine JC, Hall BJ. Problematic smartphone use: a conceptual overview and systematic review of relations with anxiety and depression psychopathology. J Affective Dis. 2017 [cited 2021 Mar 9];207:251-9. Available from: https://pubmed.ncbi.nlm.nih.gov/27736736/

20. Ministério da Educação (Brasil). Conselho Nacional de Educação. Institui diretrizes curriculares nacionais do curso de graduação em nutrição. Resolução CNE/CES 5, de 7 de novembro de 2001. Brasília: Diário Oficial da União. 2001; nov 9, Seção 1, p.39.

21. Carrotte ER, Vella AM, Lim MSC. Predictors of "liking" three types of health and fitness-related content on social media: a cross-sectional study. J Med Internet Res. 2015 [cited 2020 Nov 22];17(8). Available from: /pmc/articles/ PMC4642410/? report=abstract

22. Raggatt M, Wright CJC, Carrotte E, Jenkinson R, Mulgrew K, Prichard I, et al. "I aspire to look and feel healthy like the posts convey": engagement with fitness inspiration on social media and perceptions of its influence on health and wellbeing. BMC Public Health [Internet]. 2018 [cited 2020 Nov 22];18(1). Available from: /pmc/articles/ PMC6086030/?report=abstract

23. Carrotte ER, Prichard I, Lim MSC. "Fitspiration" on social media: a content analysis of gendered images. J Med Internet Res [Internet]. 2017 [cited 2020 Nov 22];19(3). Available from: https://pmc/articles/PMC5390113/?report=abstract

24. Pilgrim K, Bohnet-Joschko S. Selling health and happiness how influencers communicate on Instagram about dieting and exercise: mixed methods research. BMC Public Health. 2019 [cited 2020 Nov 22];19(1). Available from: https:// pmc/articles/PMC6683418/?report=abstract 


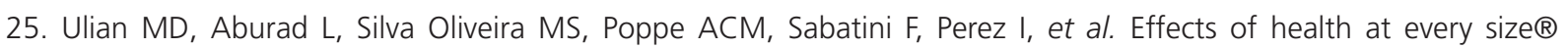
interventions on health-related outcomes of people with overweight and obesity: a systematic review [Internet]. Obesity Reviews. 2018 [cited 2020 Nov 22];19:1659-66. Available from: https://pubmed.ncbi.nlm.nih.gov/30261553/

26. Conselho Federal de Nutrição (Brasil). Código de Ética e de Conduta do Nutricionista. Brasília: Conselho; 2018.

27. Turner PG, Lefevre CE. Instagram use is linked to increased symptoms of orthorexia nervosa. Eat Weight Disord. 2017 [cited 2020 Nov 4];22(2):277-84. Available from: https://pmc/articles/PMC5440477/?report=abstract

28. Holland G, Tiggemann M. A systematic review of the impact of the use of social networking sites on body image and disordered eating outcomes. Body Image. 2016 [cited 2020 Nov 8];17:100-10. Available from: https://pubmed. ncbi.nlm.nih.gov/26995158/

29. Chan WSY, Leung AYM. Use of social network sites for communication among health professionals: systematic review [Internet]. Vol. 20, Journal of Medical Internet Research. J Med Internet Res; 2018 [cited 2020 Nov 22 ];20. Available from: https://pmc/articles/PMC5895921/?report=abstract 